\title{
Forced removals and migration: a theology of resistance and liberation in South Africa.
}

\section{Selaelo T. Kgatla ${ }^{1}$}

\section{Abstract}

This paper investigates the intensification of the scope of migrant theology by forced removals in the 1960s and 1970s in South Africa. Forced removals in South Africa were carried out by the white government, especially in the late 1950s and 1960s, with the support of the white churches (particularly white Afrikaans churches) underpinned by a series of laws which entrenched racial segregation and inequality and which led to millions of black peoples being forced to leave their ancestral land and white cities to live in barren and overcrowded places. The policy of forced removals accompanied by its resultant reprisals led to a mass exodus of many black people going to settle in the neighbouring countries either to join the arms struggle or further their studies abroad. Those who remained in the country were forced to resist the policy either through violent protest or peaceful resistance. The policy led to black people developing theologies of survival in the country of their birth since they were exposed to a condition of poverty, exploitation and alienation from their cultural heritage, while ensuring exclusive privileges to whites in the country. The paper seeks to investigate how the migrants developed a theology of resistance amidst their dislocation and the heavy-handedness of the government

\section{Forced removals enhancing migrants ${ }^{2}$ develop theology of resistance}

One of the most humiliating experiences in the history of South Africa was the forced removals of black people from their places of birth to unfamiliar areas. Laurine Platzky and Cherryl Walker published a book in 1984 entitled The Surplus People, in which they refer to those black people who were forcibly removed from their land. From the investigations reported in their book, Platzky and Walker (1984:1) tell us that from 1960 to 1982 about 3.5 million South Africans were forcibly removed from their homes and land and dumped in barren and uninhabitable areas. Millions of other black people affected by the same policy which was tantamount to reducing them to non-citizens of South Africa, fled the country. During this period, tens of thousands of children died as their families were forcibly moved and exposed to harsh conditions (Pilger 2007:197) and many others died in their transit from the country to neighbouring countries while others were

1 Prof S T Kgatla teaches in Missiology and Science of Religion at the University of Pretoria. His e-mail is: thias.kgatla@up.ac.za.

2 Forced removals were not only an inhumane measure applied to black people in order to pave the way for the policy of apartheid. Inferior education for black people, denial of economic benefits of the country, denial of political franchise and many social rights were a part of measures implemented to enforce an apartheid ideology. 
arrested under dubious laws. Excessive and brutal force was used to have the policy of separateness implemented. The irony of the system was often captured in the names given to the new places where black people were dumped. These names were coined to express happiness and safety for the victims. ${ }^{3}$ In terms of the Group Areas Act of 1950 and later 1957, various racial groups in the country were assigned to different residential townships ${ }^{4}$ and places in the Bantustans. ${ }^{5}$ The net profit of apartheid laws was to keep South Africa "racially pure" while sustaining what was called "White Christian Civilisation' through paramountcy while acting as 'guardian over blacks' (Morris 2011:35) ${ }^{6}$

The government masked the policy of forced removals under the cloak of peace and prosperity for all. White churches were directly and indirectly involved in both the design and implementation of the policy. According to Desmond (2000:16), white churches had a politically-determined understanding and a socially-determined understanding of black people and their needs. Inequality between white and black people implied that black people had limited needs, expectations, and aspirations for a comfortable life. They were regarded as not being inconvenienced through low wages, poor living conditions and lack of social services.

But the crucial question is this: what were the motives or goals for the policy of forced removals? For the white churches, Desmond (2000:13) cites self-interest, a fear of losing government privileges and endangering capitalism. From my own investigation, the following reasons were among those said to be some of the main reasons for forced removals:

- Security: As the war of liberation for South Africa intensified and cadres were attacking government targets within the borders of South Africa, the apartheid government felt more insecure. This was exacerbated by the long border stretch from Mozambique in

3 Names given to the townships included Boipatong (hiding place), Bophelong (the place of life), Guguletu (our heritage), Impumelelo (success), Masiphumelele (Let us succeed), Refengkgots (Give us peace), Seshego (African Basket) and Thokoza (Place of joy). The places where people were dumped received their names from government officials and missionaries after they had been forcibly removed.

4 A township is a racially segregated area in South Africa established by the government as a residence for people of colour.

5 A Bantustan (also known as a black African homeland in South Africa) was a territory set aside for black inhabitants of South Africa as part of the policy of apartheid and forced removals. Ten Bantustans were established in South Africa for the purpose of concentrating the members of designated ethnic groups, thus making each of those territories ethnically homogeneous as the basis of creating nation states for different black ethnic groups.

6 Morris 2011:36 argues that if Christian righteousness was ever the inspiration of Nationalist piety, it was suspended in 1950 when a plethora of apartheid laws were introduced and enforced brutally leading to imprisonment of many black people who would not respect them even if they wanted to. 
the East, Zimbabwe in the North, Botswana and Namibia in the West. It was difficult to deploy troops along such a long border and to patrol it. International sanctions also took their toll on the regime. As a way of managing the crisis, a buffer zone along the borders had to be created and maintained. White farmers had to be removed from borders to the interior of the country and space had to be created for them. Black communities were 'dispensable' and they could be removed to make the space for white farmers.

- $\quad$ Ethnic purity: Removal of people of colour from white designated areas was a purposeful policy designed by the government to remove by violent and terror-inspiring means, black people from certain geographic areas for white exclusive use. The policy was a planned deliberate removal from a specific territory, black people, by force or intimidation, in order to render that area homogenous ethnically white.

- Military bases: Some black land would make very good military bases, especially those on open plains and on mountain ranges along the Spelonken. ${ }^{7}$ Black people living in those areas had to be removed peacefully, sometimes without compensation, or forcibly if they resisted making way for military bases.

- Exclusive self-interest: Although the 1913 and 1936 segregation laws were in operation, there were still fertile patches of land occupied by black people. The government had to find a way to acquire such prime land for white agricultural farmers and government projects including military bases.

- Homeland policy: Homelands were established to achieve the grand policy of apartheid, and some of them were situated in small areas. Ways had to be found to remove people from one area to another to make room for Homelands. Further forced removals were an essential tool of the government to strip all black people of any political rights as well as their citizenship.

- Implementation of the Group Areas Act: The Group Areas Act mandated residential segregation and black people were forcibly removed to make room for the new dispensation. Many 'surplus' black people were removed from towns and dumped in reserves where they would provide cheap labour.

The government had a well-orchestrated strategy of making people move from their land to where they wanted to move them. In their reasoning forced removals were beneficial to both black and white people. In June

7 Spelonken is a farmstead area spanning north-east of the Limpopo Province of South Africa. 
1983, the then Deputy Minister of Development and Land Affairs ${ }^{8}$, Hennie van der Walt, told his audience:

I readily admit that we made mistakes in the past. So much so that black communities had to be removed by force and often resettled in critical circumstances. Our biggest mistake was that we did not undertake these resettlement actions in co-operation with the black communities. A lack of consultation between the government and the black people concerned led to numerous unfortunate incidents... The days when police had to help load people onto trucks and the resistance which followed certain actions amongst black people are past. (Classens 1984:1)

The understanding of the Deputy Minister is premised on the Afrikaner pseudo-logic that whatever the government was doing was ordained by God, since white Afrikaners were the guardians of the destiny of black people. According to such an understanding, God placed whites in Africa to civilise black people and guide them to 'prosperity'. This Verwoerdian ideology was also propounded by Prime Ministers such as BJ Vorster and PW Botha. There was no reason for black people to resist the policy of separation since it was from God. The mistake was, according to the proponents of the policy, those who implemented the policy, did not know how to deal with black people. In order to avoid international condemnation and black resistance, the government had to 'persuade' black leaders through bribes and apply a 'divide and rule strategy'. Chiefs were given incentives such as better houses at the new areas, money and farming equipment. If the chiefs would agree, they would call it a 'consultation' process. Where there was resistance, the policy of divide and rule of selective sanctions such as cutting essential services would apply. Sometimes community meetings would be prohibited. In some cases, Homeland governments would be used to help to achieve government objectives. The Homeland leaders would be instructed by their masters in Pretoria to go and convince the communities who refused forced removals to relocate (Black Sash 1984:9).

In 1970, the Bantu Homelands Citizenship Act became law. The law declared all black people in South Africa citizens of the Homelands. Even if a person was not living in or had not been to any Homeland, he or she was declared a citizen of the Homeland where his or her language was spoken. These people would be forced to apply through the Homeland under which they were relocated when, for example, they wanted to apply for a passport to go abroad. With this legislation black people became aliens in their own county of birth.

8 A department of the white government where black affairs were handled. 


\section{Theology of Resistance- Mission from the underside of history}

The South African struggle for liberation was internationally recognised as a just and legitimate struggle. In 1966, the General Assembly of the United Nations labelled apartheid as a crime against humanity and in 1984 the Security Council endorsed the determination. ${ }^{9}$ The black people of South Africa fought the system not only because of the atrocities committed against them which were based on racial segregation and criminalisation which included torture, inhumane treatment and a deliberate imposition on a racial group whose new living conditions were calculated to cause its destruction. On the other hand the Afrikaans government believed it was their God given obligation to bring the virtues of social justice that included peace, justice and dignity to the black population. Jesus Christ said he had '...come in order to that they (all) might have life in its fullness'. Biblical injunctions such as equality, justice and possession of land to all those who lived in the country were embedded in policy documents that informed the black struggle.

It is also argued ${ }^{10}$ that almost all the Presidents of the African National Congress (ANC) were confessing Christians. The ANC roots were Christian and it derived its moral vision from the church (Mandela unpublished paper). Its founding leaders brought their rich liberation theology matrices. Religious leaders such as the Rev John Dube, Mangena Mokone, Tiyo Soga and many others brought a profound contribution of Christian presence into the movement. It is said that at the founding congress in 1912 delegates spontaneously broke into the song 'God of truth fulfil your promise (Motshekga 2010:1). Biblical motifs such as exodus as articulated in Albert Luthuli's autography 'Let my people go' and the national anthem 'God save Africa' were common features of the struggle that inspired black people. It is therefore argued in this paper that the black struggle for liberation and justice was based on sound theological grounds and the liberation movement did the work which was supposed to be done by the church. The goal of the struggle was to benefit all those who lived in South Africa (Tukor 2011:21-40).

This paper argues that the removal and migration of millions of black South Africans as a result of the apartheid laws in the early 1960's and 1980's had a missiological significance. Many migrants who were both forcibly uprooted and suffered internal displacement fled the country because of possible arbitrary detentions without trial with their resultant life imprisonment; complex as this might be, this needs a theological

9 See General Assembly Resolution 2202 A (XX) of December 1966 and Security Council Resolution 556 of 23 October 1984.

10 see Majola 2012, Rakolote 2013, Grundy 2012, Motshekga 2010 and Mandela 1994:172 
perspective (Groody 2009:638). The objective of this paper is to argue that in a mystical way God was involved in the plight of the oppressed and poor as He was energising them to do what was His will and according to His pleasure (Kgatla 2012:7). The paper discusses the nonviolence resistance of broader liberation movements in the 1950s, peasant revolts of the same period and the Black Consciousness Movement Philosophy of retreating from white structures and mobilising for peaceful struggle.

Migration should not be viewed in the stereotypical way of poor people entering a more developed country seeking better living conditions (Migration Studies Project 2013:1). Migration includes the massive displacement of people within a state because of destabilising factors such as war, forced removal of people from their birth places, arbitrary detentions and torture, people fleeing from their country because of terror unleashed by the state (:1). Scholars like Lewellen (2002) and Castles (2000) encouraged the adoption of the term migratory process and considered the movement of people as an interlinked activity or a systems theory in order to study the phenomena in a holistic manner.

Black struggle for liberation in South Africa can be studied as a migratory process that took many dimensions. It was, however, always peaceful until excessive force from the side of the government was used and some black organisations resorted to an armed struggle (Biko 1996:29). In the 1950's, the methods used by the major black political organisations were always peaceful. The African National Congress Freedom Charter of 1955 spelt out their goals for the whole country. This document stated that South Africa belonged to all [people] that lived in the country (Turok 2011:32). The adoption of the Freedom Charter demanded that land should not be left in the hands of a few whites, education should not be used to domesticate people but liberate them, radical economic reforms that would benefit all South Africans despite the colour of their skin, and the overall objectives of changing the nation. The clear, unifying statements of the Freedom Charter unified and mobilised those who were opposing apartheid to resist the injustices of the system.

Theologies of resistance in the time of the struggle against apartheid atrocities in South Africa were condemned by the white churchesespecially those who aligned themselves with the government. Scripture texts such as Matt. 5:38-41; Luke 6:29, Roman 13:1-6 were used by security forces as a basis for meeting black resistance to the system with force (Farisani 1987:28-29). The oppressed black people were not supposed to resist an evildoer. The correct reading of Jesus teachings and life with regard to evil was resistance more of methodological approach. Wink (1998:98-11) argues that Jesus taught his followers to resist evil with every being of their fibre. Jesus wanted his followers to take a stand against evil but in such a way that they should not fight evil on its terms (1998: 98). He 
urged them to transcend both passivity (that the powerful and privileged would call upon their oppressed to observe) and worldly violent ways. Jesus wanted his followers to shame their oppressors by not cooperating with them and refrain from using their methods of enforcing compliance (violence). Wink calls this Jesus Third Way. 'Because the powers that be are literally standing on the dignity of their subjects; nothing would deflate them more effectively than 'deft lampooning' (1998: 110). By refusing to be awed by their power, the powerless seize the initiative. Jesus' teaching on non-violence provides a hint on how to unmask the cruelty and injustices. The essence of Jesus' teaching on non-violence does not approve passivity or violence. His followers had to follow a way in which violence could be opposed without 'being mirrored', and the oppressor 'being resisted without being emulated, and the enemy neutralised without being destroyed' (:110). Jesus offered a third way from ingrained options of 'flight or fight', a third way of opposing without being mirrored.

This method of nonviolent resistance to racial oppression was adopted by Martin Luther King $\mathrm{Jr}$ when he attested that it gave them new self-respect, and calls for new strength and courage they did not have previously. ${ }^{11}$ In South Africa the liberation movement adopted a strategy of non-violence through defiance campaigns, peaceful protests and various nonviolent protests and demonstrations until the Sharpeville Massacre of 21. March 1960 (Turok 2010:79). The Black Consciousness Movement embraced a nonviolent method in the emancipation of black people through retreat from white structures and a development of a self conscientiousness into a true humanity (Biko 2004;101-108).

Wink (1998:98-111) identifies the following virtues of Jesus' Third Way of responding to violence:

- Ability to seize the moral initiative

- Creative alternative to violence

- $\quad$ Ridiculing force with humour and humility

- Taking control of the power dynamic while exposing the injustice of the evil system

- Stand your ground and allowing the powerful to make decisions which they are not prepared for

- Deprive the oppressor of a situation where show of force is effective

The principles of equality before the law as set out in the Freedom Charter were not only unifying to those who wanted peace and justice in the country but were also enhancing their Christian beliefs and justice as the majority of

${ }^{11}$ Martin Luther King statement My Pilgrimage to non-violence on 1 September 1958 New York 
them was believers. ${ }^{12}$ People who were displaced, oppressed and dispossessed and seeking to be reincorporated into their country of birth saw them as the basis upon which they were resisting the apartheid system. These principles are based on fairness, equality, justice, human dignity and the Bible teaching of social justice. Unlike apartheid being determined and enforced exclusively based on ethnicity and the racial prejudices of the apartheid system the virtues pronounced in the Freedom Charter are biblical. These principles were espoused in a number of ways but they aimed at the emancipation of everybody in the country. Those who were displaced from their land either forcefully or fleeing for their safety to outside countries or incarcerated, were fighting the system that dehumanised them without wishing away those who committed injustices received any retribution for their deeds.

\section{Biblical foundation of freedom and social justice}

According to Wheaton (2008:1) this entails two key components: social 'living together in communities or organised groups' and justice - 'the upholding of what is just, especially fair treatment and due reward in accordance with honour, standards, or law. Combining these two concepts Wheaton comes up with the definition of social justice existing when people get what they are due from their particular group or community. The opposite of social justice (injustice) occurs when people do not get what they deserve, including equal opportunity to work and the wealth of the country and its resources. Jesus said in John 10:10 that He came so that they might have life and have it more abundantly.

Metzger (2010:1) states that Biblical justice involves making individuals, communities, and the cosmos whole, by upholding both goodness and impartiality. Biblical justice stands at the centre of true religion, which includes looking after orphans, widows the poor and downtrodden as James 1:27 and Proverbs 29:7 would put it. Justice like mission flows from God's heart and character. The constant danger the apartheid government faced was downplaying social justice while highlighting personal morality and piety (Morris 2011:36). Jesus rebuked the Pharisees: "Woe to you, teachers of the law and Pharisees, you hypocrites! You give a tenth of your spices-mint, dill and cumin. But you have neglected the more important matters of the law- justice, mercy and faithfulness"(Matt.23:23). Parsons (2014:2) compares the convictions of Zealots ${ }^{13}$ : They were entirely sincere in their convictions but they were sincerely wrong. They killed those who differed with them. In the history of

12 ANC was built on Christian principles as espoused by their founding fathers who were clergy. This was also the case with the Black Consciousness Movement which was formed by the Student Christian Movements.

${ }^{13}$ Zealots were one of four Jewish sects during the time of Jesus Christ. 
South Africa many black people who openly differed with the government were killed.

Transformation of both individual and community are part of restoring wholeness to people (Kgatla 2013). It is only with transformed hearts that people can extend God's justice to the poor, orphans and widows, and partiality to all. These concerns were exhibited in the lives of those who resisted the evil of apartheid and embraced a theology of life that would eventually emancipate them. In many respects they stood where the church was supposed to stand and became a manifestation of God's kingdom.

\section{Black South Africans' Resistance to Racial Dominance}

The black resistance to apartheid took various forms at different places in the country. The major struggle took place in urban areas ${ }^{14}$, rural areas among peasant people and at Universities as well at schools. In this paper these components are discussed separately.

\section{Urban Struggle}

"The African's Claims in South Africa" adopted by the annual conference of the ANC, in Bloemfontein on 16 December 1943 clearly elucidated full citizen rights and demands (Turok 2011:21). These included the abolition of political discrimination, right to equal justice, freedom of residence and movement, recognition of the sanctity of inviolability of the home as a right of every family, the right of ownership and many others. The demands included land, industry and labour, commerce, education, public health and medical service. All these rights and demands were ignored by the white government despite the virtues espoused in the Freedom Charter of 1955. The response of the white government was a rejection of African political aspirations and this was intensified after the 1948 election when many racial laws were implemented. Black South Africans had to respond but first in peaceful ways through defiance campaigns, boycotts and non-compliance with discriminatory laws (Turok 2011:40-50). The white rulers were left with no doubt of what Africans wanted.

The target of the defiance campaigns was against unjust, oppressive laws (Turok 2011:48). The intention was to disobey these laws, suffering arrest, assaults, and penalties without violence. The method was to send in groups of carefully trained 'volunteers' to disobey publicly. This was at a time when a brace of laws were passed and dispelled no doubt about the white governments rigidity in ordering society and economy by race, their determination to use force in enforcing their racial laws. In the midst of all these ambiguities and contradictions black people remained focused with

${ }^{14}$ United parties who adopted Free Charter under the ANC were more pronounced in urban areas with rural people waging their own resistance in the country side, and students at Universities and High Schools resisting apartheid from their academic situation. 
the simple but effective strategy of non-violence but disruptive: volunteers would break discriminatory laws, compelling the police to arrest them.

With the white government wanting to reverse the core history of South Africa by arresting black people's movements from the country side to towns and cities, and the growing mobilisation of the black masses against oppressive laws, an irreversible pressure was mounting on black people to deepen the spirit of resistance (Morris 2011:44-45). Resistance became a living reality for black people, an inspiring faith towards freedom.

\section{Rural Struggle: The Peasants Rise}

The removal of black people from their fertile ancestral lands to errant batches of land, low wages the white farmers paid to their black workers, the inhumane conditions under which they lived and worked, racial prejudices accompanied by brutal enforcement towards those who resisted to comply and many other grim realities of apartheid triggered unprecedented resistance from black people (Turok 2011:41). Errant and over grazed and over populated reserves were causing an increasingly inability to provide sustenance for the peasantry and attempts from government to restore them worsened matters. The culling of stock to the carrying capacity of the communal pasturage, and the removal from residential areas of people to other areas did not solve the problem. As black people were forced to occupy only $7 \%$ of the total land there was no way that their lot could improve but instead became worse (Turok 2011:41).

Instead the peasants fought back by destroying the fences the government had put up to fence off the communal pasturage. The government retaliated by holding the neighbouring communities responsible and imposed a collective fine served only to provoke whole communities to join the resistance of the national struggle for liberation (Mbeki 1964:np). The stringent implantation of a culling system, which limited the number of stock to the carrying capacity of the pasturage, aggravated the situation. Many black households were left without enough stock for farming. White officials who were responsible for culling the stock were full of vengeance and culled the stock that could withstand the draught and left old animals (Farisani in interview 8 December 2013). Tractors could be an alternative for ploughing and many black people boycotted them as they were owned by the very people who were engineering their hardship. Consequently the land was left fallow, and the alternative was to flood white cities in search for employment. Many black people who moved to the cities for employment became victims of influx control regulations and they were sent back to their overcrowded homelands. The consequences of these developments forced black people to find themselves trapped between abject poverty and the hammer of the law that evicted them from 'white areas' (Mbeki 1964). 
Despite the enforcement of the apartheid policies by harshness and force, the rural people of South Africa never relented in their resistance. Albert Luthuli summed it up in 1962 as the African voice 'we do not consent' to apartheid laws (Luthuli 1962 in Turok 2011:42). Between 1946 and 1962 peasants resistance was provoked in Witieshoek, (Freestate), Marico and Sekhukhuneland (former Transvaal), Zululand (Natal), The Transkei (Eastern Cape) and many parts of rural South Africa (Mbeki 1964).

\section{Radicalisation of Youth through Black Consciousness Philosophy}

The Black Consciousness Movement's (BCM) origins were deeply rooted in Christianity. Like its counter-part in America Black Power in the mid 1960s the BCM in South Africa became disillutioned by the spirit of 'black and white together' in the struggle for justice (Biko 2004:3-5). They had a feeling that the presence of white (students) in the movement was inhibiting the growth of black pride and initiative. Consequently the BCM attached what they called traditional white values, especially the 'condescending' values of white liberal thought. They mobilised their members to reject white 'monopoly' on truth as a central tenet of their teaching. "Black man, you are on your own" became the rallying battle cry as they engaged themselves in the creation of community activities to advance their 'liberating and empowering' programmes. Their swelling mobilisation of the youth and communities to reject prevailing government philosophy of separateness provoked the wrath of the security apparatus of the government.

Events such as the formation of Christian Organisations such as the South African Student Organisation (SASO), University Student Movement (USM), Bold Evangelical Christian Organisation (BECO) and Pre-Frelimo Rallies in 1974 and many Church-related revivals and experiences the youth had with the apartheid system in schools and their communities played a major role in the intensification of resistance against the apartheid system (Kgatla 2013:7). Learning from the mass liberation struggle, banning of political organisations and the promotion of a discredited Homeland system and the incarceration of authentic political leaders in Robben Island increased the scope of the students understanding of the brutality of the system. The Bantu Education System and its effects were a common cause for the students.

The South African Black Youth, who came from a strong Christian background, immediately became aware that Christian salvation should be understood holistically. Salvation without social justice is a deceitful ideology. The task of the Church was therefore to serve God in Jesus Christ by the spirit for the sake of all (Kgatla 2013:7). Accordingly the BCM called for resistance against the unjust policies of apartheid, authentic 
human freedom for all, black pride, and unapologetically fought against increasing white supremacy (Biko 2004:135-156).

\section{Conclusion}

In this paper I argued that the concept of migration is wide and complex. Many black people in South Africa were forcefully removed by the government; some were forced to 'migrate' to overseas countries, some moved to towns and cities on their own while their leaders were incarcerated in Robben Island. These masses of people were sustained by an African Theology of Liberation and they fought the right battles for their own authentic freedom. The resistance to apartheid took many forms at different levels and time. Blacks living in towns and cities used the necessary means at their disposal to resist evil while those in rural areas also used their own strategies. Black students at Universities and high schools used their own strategies relevant to the circumstances in order to liberate themselves.

\section{Bibliography}

Biko, S. 2004. I write what I like. Johannesburg : Picador Africa, 2004.

Castles, S. 2000. Ethnicity and Globalization. London : Sage, 2000.

Classens, A. 1984. The Myth of Voluntary removals. Sash, Vol 27 N0 . May 1, 1984.

Cohen, R. 2009. Special Report, Acess Denied: Medical and Humanitarian Needs of Zimbabweans in South Africa. MSF Head of Mission in South Africa. s.l. : Unpublished, 2009.

Crossing the divide: Foundations of a theology of migration and refuges. Groody, D. 2009. September 2009 638-667, 2009.

Groody, D. G. 2009. September 2009 638-667, Notre Dame : University of Notre dame, 2009, Vol. 70.

Farisani. 1987. Dairy from a South African Prison. Minneapolis : Fortress Publishers, 1987.

Grundy, T. 2012. ANC recalls Christian roots. s.l. : cja-uk, writing in Ecumenical News International (ENI), 2012.

Jesus' Third Way. Wink, W. 1998. The Power that be: Theology for a New Millennium, 1998.

Kgatla, S. T. 1992. Confirmity, Change and Conversion among the Northern Sotho People: Towards a Missiology of Self-Transcendence. Unpublished DTH thesis submitted to the University of South Africa. Pretoria : UNISA, 1992.

Kgatla, S T. 2013. The Transformational, Intersectional and Transcendental Agenda of Mission: Quest for a Spirituality of the Road. Series of Association of Professors of Mission 2013. First Fruits Press. Wilmore, Ky.

Lewellen, T. 2002. The Anthropology of Globalization. London : Bergin Garvey. 
Lutheran and Reformed Clergy resisting Venda Government in 1970/80s. Kgatla, S. T. 2013. s.l. : Unpublished paper compiled for the role of German Churches in South Africa., 2013.

Majola, M. nd. The Role of Christian Leaders in the Formation of the ANC. http://rejoicebc.co.za/formation.html. [Online] nd. [Cited: January 29, 2014.]

Mandela, N. 1994. Long walk to freedom. Edinburgh : Clays Ltd, St Ives plc, 1994.

Mbeki, G. 1964. The Peasants' Revolt. http://www.marxists.org/ subject/africa/ mbeki/ peasants-revolt. [Online] 1964. [Cited: January 23, 2013.]

Morris, M. 2011. Apartheid: An Illustrated History. Johannesburg : Jonathan Ball Publishers, 2011.

Motshekga, M. nd. National InterFaith Council of South Africa (NICSA). s.l. : Unpublished, nd.

No room for compromise: South African Churches and Apartheid in Innovation. Desmond, C. 2000. s.l. : Innovation, 2000, Innovation 20 June 1994.

No room for compromise: South African churches and apartheid in Innovation. Desmond, C. 2000. N0: 20 June 2000, 2000.

No room for compromise: South African churches and apartheid. Desmond, C. 2000. s.l. : Innovation, 2000, Vol. N0; 20.

Pilger, J. 2007. Freedom Next Time: Resisting the Empire. New York : Nations Books, 2007.

Platzky, L. \& Walker, C. 1984. The Surplus People: Forced Removals in South Africa. Johannesburg: Ravan Press, 1984.

Radebe, J. 2013. Joined at the hip: The church and the African National Congress. s.l.: Unpublished, 2013.

Turok, B. 2011. Readings in the ANC Tradition> Volume 1 Policy and Praxis. Auckland Park: Jacana Media, 2011. 978-1-77009-969-2.

Wegerif, M. Russell, B. \& Grundling I. 2005. Still searching for security: The reality of farm dweller evictions in South Africa. Polokwane: Nkuzi Development Associaton, 2005.

West, C.C. 1999. Power, Truth, and Community in Modern Culture. Harrisburg: Trinity Press, 1999.

Wheaton, J.D. 2008. Life is not fair. Christian World View. Deposited Sunday 2 November 2008, 2008. 